\title{
Feeling Medusa: Tentacular Troubling of Academic Positionality, Recognition and Respectability
}

Shiva Zarabadi, PhD Research Student and Teaching-Fellow, BA(Hons), MSc. UCL Institute of Education, Department of Education, Practice and Society, Shiva.Zarabadi.15@ucl.ac.uk Carol A. Taylor, Professor of Higher Education and Gender, BA (Hons), MA, MA, MSc, PhD. University of Bath Claverton Down, Department of Education, C.A.Taylor@bath.ac.uk Nikki Fairchild, Senior Lecturer, PhD, MA (Ed), BSc (Hons). University of Portsmouth, St. George's Building, nikki.fairchild@port.ac.uk Anna Rigmor Moxnes, Associated professor in Pedagogy, University of South-Eastern Norway, Institute of Pedagogy and Educational Science, anna.moxnes@usn.no

\section{Abstract}

This article explores a series of tentacular troublings inspired by Donna Haraway's (2016) concept of String Figuring (SF). We consider these troublings as relational entanglements which produce perturbations of our gender, positioning, recognition, and respectability as feminist academics in Higher Education. We activate tentacular troublings as a refrain for contemplating differences/ings in our academic lives and as a critique of contemporary neo-liberal academia which ossifies, fixes, and freezes feminist flows. The article makes two contributions. The first is to deploy string figuring as a proposition for feminist thinking which troubles the notion of fixed positions in favour of position(ings)-plural in motion. The second is to enact string figuring as a mode of ecriture feminine (Cixous, 1976) in which connections are made, dropped, and picked up in tentacular relays and patterns of entangled encounters, thereby perturbing normative modes of writing and troubling traditional modes of knowledge making. Feeling Medusa helps us with this work. Medusa, as powerful woman, Amazon goddess and gorgon, and vilified proto-feminist whose glance turns men to stone is knotted into our perturbations and troublings; her presence informs and inspires our SFing.

Keywords: String figuring, tentacular troubling, perturbing, ecriture feminine, position(ality), feminism. 


\section{Stringing 'we': First walking ... then talking ... then writing ... and walking ... and talking ... and writing ... and}

We are four academics who came together after a "walking with string" workshop run by one of us to pursue a shared interest in analysing perturbing positions - a notion which has multiple inflections. In particular, we use "perturb" to refer to, and enact, a feminist mode of productive unsettlement in our thinking and writing practices which seek to disorder, trouble, confound and confuse normalized positions and normalizing positionalities which contain and constrain us as academics in higher education (HE). Our experimental exploration of perturbing positions makes a contribution to PhEmaterialist understandings of what it can mean for us, as female academics at various stages of our careers, to work in and be part of the neoliberal university. The call for papers asked for a consideration of "How do the principles of feminism posthumanism and new materialism recalibrate and reimagine what matters for educational research, pedagogical and political practice?" In responding to this urgent question, we turn to Donna Haraway (2016) and string figuring (SF), among other new materialist and posthuman thinkers, as a means to do two things: one, to pursue thinking-in-movement with regard to our perturbing position/alities as higher education academics; and two, to offer a (com)positional instantiation of SF writing-as-four-together which brings an ecriture feminine (Cixous, 1976) into play.

These aims are strung together with some key forebears who inspired us: Medusa and Helene Cixous-Medusa, the gorgon whose piercing look turns men to stone and Cixous, whose text, The Laugh of the Medusa, inspired us to try our own hand at writing ecriture feminine. Together, Medusa-Cixous enable us to feel-think-write a non-linear SF materialization of our position/alities. They encourage us to experiment with the inclusion of images, poems, vignettes, different layouts, screenshots, notes in boxes, and comments on our personal experiences and our collective experiences together at conferences and in writing this piece. The article emerges, condenses and materialises from this deliberate pass at non-linearity so that we might "present" our various troublings of academic positionality, recognition and respectability in the textures, differences and dissonances of the writing as it unfolds as a lively assemblage of our (ongoing) experiences, memories, thoughts and feelings. We realise this may make our article a somewhat bumpy ride for the reader! Our intention is that it communicates in some ways how "we four" as writers, thinkers, academics are tentacularly connected. Our hope is that the tentacular troublings work as a form of string figuring (SF) refrain (Deleuze and Guattari, 1987) throughout the article: string is passed back and forth between us, just as thoughts, feelings, doings, and knowings pass between us. Such passings dis-order the refrain and help us enact tentacular writing which brings together multiple passings at staying with the feminist trouble that string figuring provokes in our thinkings-feelingsdoings-becomings in higher education. 


\section{String Figuring Positionalities with our Feminist, 'Feminal' Forebears}

In rethinking positionality, we think-with Medusa, her snaky hair, her piercing look and think-with Haraway's (2016, p. 31) "leggy spider" and her "many armed allies". We are entangled in the SF tentacles of our thinking which weaves open paths and knots attachments.

Medusa arrives first. Medusa inspired us, inviting us to think-feel-with her in stringing our stories. We entangle with Medusa via Cixous (1976, p. 885), whose joyful writing and thinking with Medusa urges us to think-feel-with the joy of Medusaen togetherness too. For Cixous, the laugh of the Medusa offers a feminist standpoint that utilizes feelings and humour (qualities attributed to women), which stand in opposition to male rationality and thinking (Gaten, 1996). Feeling Medusa is, for us, a mode of being-becoming that we utilise to position ourselves against historical, positivist, Euro-Western thought that excludes women and other bodies as non-white-male mainstream. Cixous is our kin; Medusa is our kin.

Haraway turns up next, conversing about her SF philosophy as string figures, as speculative feminism, science fact, speculative fabulation, so far. We hear her saying that:

Playing games of string figures is about giving and receiving patterns, dropping threads and failing but sometimes finding something that works, something inconsequential and maybe even beautiful, that wasn't there before, of relaying connections that matter, of telling stories in hand upon hand, digit upon digit, attachment site upon attachment site, to craft conditions for finite flourishing on terra, on earth. (Haraway, 2016, p. 10)

We laugh with Medusa while string figuring our bodies, stories and feelings with Haraway. We are soon stringing, walking and making. We entangle Haraway's string figuring (2016) and Cixous's laughing Medusa. Together they move us, provoke us to feel and think about our bodies, stories and positionalities in higher education differently. SF-ing with Haraway-Medusa enables us to know otherwise (Pedwell and Whitehead 2012, p. 119). SF-ing with Haraway-Medusa suggests that "in order to know differently, we have to feel differently" (Hemmings, 2012, p. 150).

And other feminal forebears join us in tracing the contours of generational feminisms (Van der Tuin, 2015) so that we can become more alive to the genealogical inheritances of our foremothers. We are inspired by Haraway's $(1988,2016)$ call for situatedness, which centres feminist knowledge making practices, and we employ this to consider the "body" as a site of connectedness and relationality (Grosz, 1994). Barad (2007) is here too, of course, and she prompted us to consider processual string figurings across different temporal and spatial entanglements, who helped us bring into play an awareness of the mattering of our multiple spacetimematterings to our ongoing positionalities. Braidotti's (2013) development of critical posthumanist thinking, which pushes again the rationalized, white, masculinized Eurocentric Enlightenment gaze, is also present with us. These powerful feminist thinkers offer us strong and stringy PhEmaterialist lines which connect us with Cixous (1976) and the multi-voiced nature of ecriture feminine through which our four-person string 
configuration is articulated. These feminist knots and connections affirm feminist "movement" (Van der Tuin, 2015, p. 117) which we continue in this article.

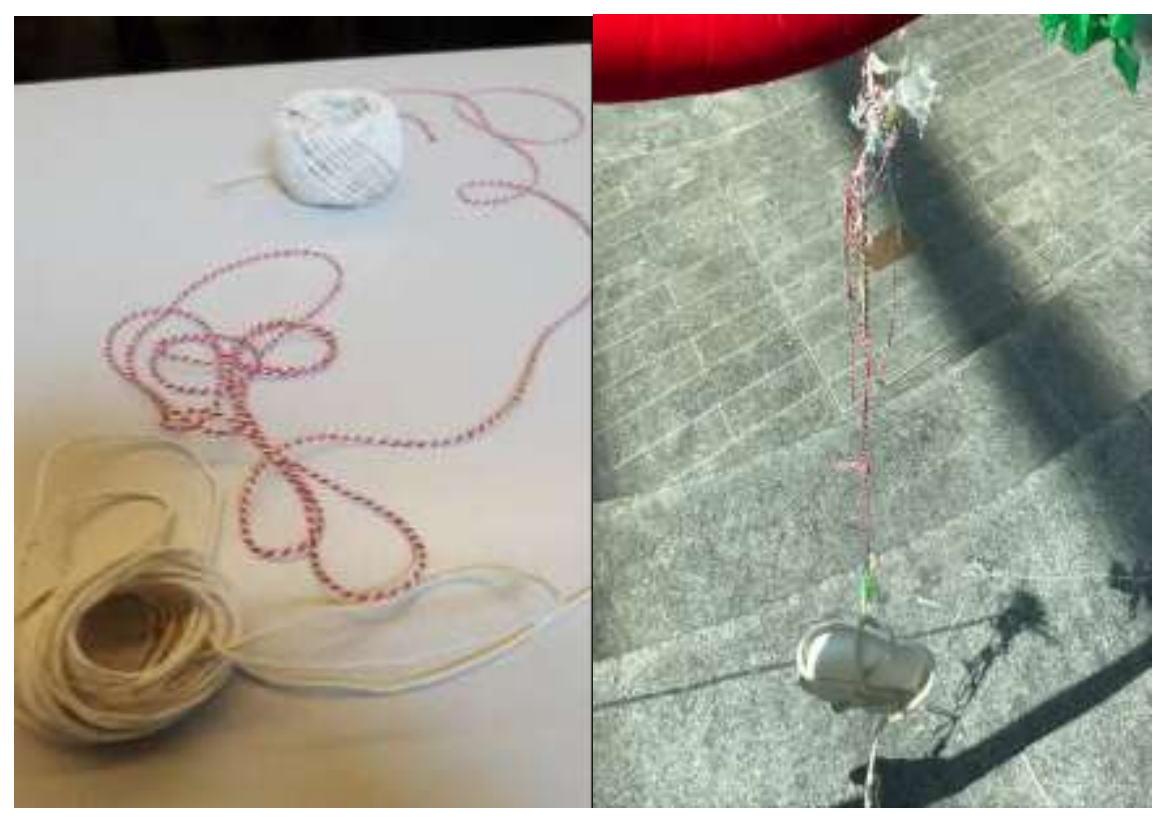

Moment: In and beyond the workshop

\section{What Did We Do? Ah, Such a Deceptively Simple Question!}

There is a Walking with String event at a university in Leuven led by one of us. A year later there is a PhEmaterialisms event at Middlesex University led by others of us. Various configurations of us meet, walk and string at both. We walk with string, positioning string figures in university spaces, we photograph them. In different space-times we are at home, in our university offices, in cafes, where we talk, read, listen, write, laugh, talk more, Skype, write, read, shuffle text, write into, write over, write amongst the emergent words, sentences, paragraphs, images. Each event gives rise to stories, matters and bodyings regarding the connections which clot and knot our position(alities), making maps of our human-and-more-than-human feminist livings: our intersectional positions, our $\mathrm{im} /$ possible positions, our im/positions, our feminist positions, our writing positions. Each event proliferated, leading to more unforeseen perturbing positions and raising yet more questions about our individual-relational perturbing positions in our various geographically dispersed orientations in our respective universities. We often write of these events in the present tense (when we are feeling-Medusa they feel/are present!), just as we often write of "later" events in the present tense too - although sometimes we use the past tense. These tense-ing changes are our experimental attempt at stringing our ecriture feminine so that we may extend our doings into the present - so that the events continue their presentings. In doing this, we deliberately work against the past tense of "reporting and representing" at a distance that can be found in more traditional qualitative work. Unlike such work, our stringing is never "over" and "finished', never "done". 
As well as what we "did" (are doing) with string, our ecriture feminine as multi-voiced-embodied article is also about "us" as "we" - a "we" that continues to emerge and continues to make trouble in relation to our disturbing positionalities concerning being feminist higher education scholars. Becoming "we" makes making trouble in the academy more possible, more thinkable, more actionable. As feminists, not only do we need our feminal forebears, we also need our "we"s - those connecting fibres and clots of solidarity which, however shifting, temporary and (sometimes) contentious, move one into alliance with two and three and four and more. Becoming-we offers a Medusaen-kinship with Cixous's woman (1976, p. 893), who is "arriving over and over again, does not stand still; she's everywhere, she exchanges, she is the desire-that-gives."

Becoming "we" in this way, and writing-together about positionalities plural, makes us ponder other modes of writing "about" experience and how our writing-thinking-doing might trouble those modes. We are cognisant, for example, of autoethnography (and duo-ethnography and trio-ethnography) as a methodology. But these modes of writing are still based in presumptions of individual-bodied-ness and of bodies with boundaries. They also presume that there is such a thing as "personal experience ('auto') which can be described and interpreted ('graphy') in relation to cultural texts, experiences, beliefs, and practices ('ethno')" (Adams et al., 2017, p. 1), the latter also presumed to be separate from the individual body. What we are doing differs from the lineages of autoethnography, which recentre human experiences as a focus for knowledge production (Adams and Holman Jones, 2018). In contrast to these, we consider our feminist commitment to SF and ecriture feminine as a postpersonal mode of bodying - as a material connectivity and "movement by which corporeality surpasses itself" (Massumi, 2014, p. 30). This attention to the immanent nature of bodying allows us to reshape that which constitutes the "auto" and the "ethno" and the "graphy" and to reconceptualise it as a post-personal eventful process. Our bodying connections usher in an event of Medusaen-kinship, a unique and everchanging practice where:

Higher education ... research, and academic writing ... unfolds as processual relation of enjoyment in which flux and impermanence point to an open future. Not everything is decided in advance. A post-personal academic life would open up more scope not just for acting well in-relation to human and nonhumans bodies, things, materialities of all kinds (Taylor, 2017, p. 119). 


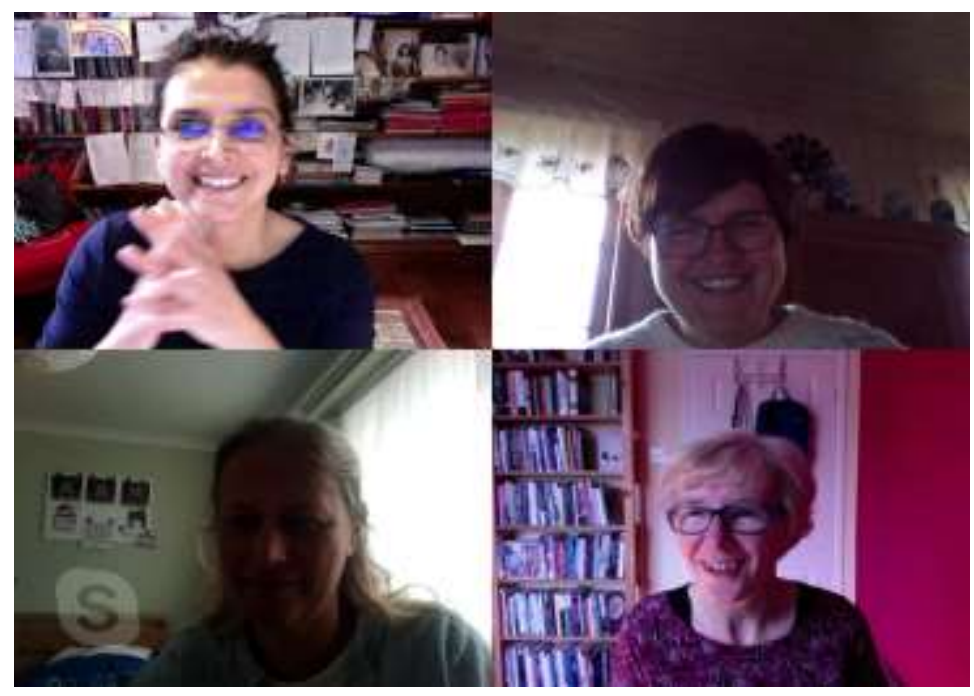

Moment: Tentacular-ed us

As so, "we" continue bodying and becoming "we" in our entangled, tentacular, post-personal desires as we continue moving beyond fixed, boundaried and dualistic subject/object identities and as we (continually) (re)calibrate and (re)imagine our feminist position(ings) within and to our differently situated higher education contexts. Our string figurings play re/figure our ontological position(ing)s as we talk, Skype, and write, each relational event producing capacities to ponder and play with our heavy and thick positionalities as differentially positioned academics by attending to the differentiations produced by our bodily positioning in the room, faces, walls, curtain, lights, sounds (see Moment: Tentacular-ed us). String figuring in materialist mode of playing-working-thinking (Hughes et al., 2018, Wolgemuth et al., 2018) provokes thinking-feeling which troubles normative positionalities.

\section{Rethinking Academic Positionality}

You might position us thus in a traditional sense. One of us recently passed her public defence (Norwegian: disputas), thereby passing into the status of "Doctor", someone who has acquired the normative position/ing of "proper" academic, someone whose knowledge has been judged, approved of, accredited. One of us is a senior academic whose academic career has been shaped by working at the interstices, whose position/ing was always a matter of trouble, was always a question of gender, class, location, discipline, field, research focus. One of us troubles her gendered racialised not-yet-academic-position with different vague tentacular positionalities between possibilities and impossibilities. Can she ever pass into the position of "Doctor"? One of us still feels like an imposter and wonders if/when this will change. But such position(alities)s are already undone. Since that sentence was written time has passed and "we" are becoming something-other. We know that being a feminist academic in the neoliberal academy guarantees in advance a certain sort of positioning. We also know-feel-sense that doing writing otherwise and attempting to keep meaning on the move perturbs the presumed boundaries of 
voice/body/thought. These are ways of stringing openings for doing-being in the academy differently.

And so, we come to think that tentacularity opens pathways to positionalities-plural, to position(alities) as an onto-geography. Such thinking moves away from positionality as a fixed point in time and space (as in Cartesian humanism), or as a singular or linked set of attributes (race, class, gender, for example), or as discursively established through differential positions (Braidotti, 2013). Instead, string figuring a feminist materialist - a PhEmaterialist - onto-geography figures positionalities-plural as a mode of event (Manning and Massumi, 2014). Positionalities become intensities, vibrations, relations (bodily and otherwise) which gather to them an openness that connects and produces changes in connection with other events materialize the body-in-relational. Positionality thus becomes com/positionality, a choreographic materializing in the moment, a thrown-togetherness of happenings.

Position is always-already gendered. As noted above, the position of "female academic" is a marked position in relation to the presumption of normal male. How then might positionalities-plural - and com/position multiple - have scope to undo the positions-as-usual of academic recognition and respectability? Becoming un/respectable is risky and troubling. A feminist allegiance to com/positionality is (continues to be) productive of precarious and unsettling doings and is undoubtedly entangled with compromises and vulnerabilities that attend and harm women's bodies in all sorts of particular ways. Rethinking positionality is, then, an orientation to staying with the trouble where gendered bodies are concerned.

\section{Stringing-With Anonymous Hedgehog in Academic Onto-Geographies}

The tentacular troublings in this article are un/structured. They offer a mode of feminist resistance, of ecriture feminine (Cixous, 1976), to the hegemonic expectations of knowledge production within the neo-liberal university (Stengers and Despret, 2014) and move beyond the frame of business-asusual in article writing. Writing tentacularly with SF produces this article as a heterogeneous assemblage, as a range of response-able, relational contact points which do not (aim to) tell a "straight story," but rather, chart the/our expansive movements of spacetimemattering (Barad, 2007) across locations (Leuven, Middlesex, Sheffield, Kongsberg, Bath, Central London, Chichester) and conversations (Google docs, Skype).

Thus

So

And 
In place of linearity, we invoke the refrain, with its rhythmic, unstable and improvisational repetitions with/and differences (Deleuze and Guattari, 1987). We deploy the mode of refrain diffusively to dis/order our writing, aligning with our sense that feeling with Medusa offers an intensive undoing of fixed positions.

Writing as ecriture feminine refrains is a dynamic style-content mesh which undoes traditional stylecontent separations. In this, our writing is allied with the growing body of post-qualitative work which questions and plays with the nature and form of academic writing (Otterstad and Waterhouse, 2016; Waterhouse et al., 2016; Benozzo et al., 2018; Niccolini et al., 2018; Benozzo et al., 2019; Taylor et al., 2019). Some see this type of writing as cyborg writing (Muhr and Rehn, 2015; Prasad, 2016); some see it as "madness" (Gale, 2018). Feeling Medusa, we see its twists and turns, its turns and re-turns, as a means to enact feminist perturbances which unfix position(alities) and their alignment with academic recognition and respectability. This is not SF writing as grand narrative but as "modest [feminist] possibilities for partial recuperation and moving on" (Haraway, 2016, p. 10). As Cixous (1976) indicates, ecriture feminine puts ourselves into the text - into the world and into history - not as boundaried beings but as a technique for "composing with creative practice, for composing emergent collectivities, for composing thought in the multiplicitous act" (Manning and Massumi, 2014, p. ix).

Thus

So

And

The injunction highlighted by Bev Skeggs (1997) on working-class women to "become respectable" has shaped our trajectories in the academy. Challenging "respectability" knots us together in the current climate of populist politics and hate speech, where a more right wing mode of thinking seeks to marginalise working-class women, women of colour, non-Anglophone women. We feel these tensions in our daily lives in our respective universities. Medusa becomes a figuration of resistance for us. Medusa, the snake-haired Gorgon, who turned those who looked on her face to stone, materialises in our own constantly fluctuating and passing positions. When we Skype we share our experiences, materialising moments of solidarity, and we laugh.

We often Skyped and worked into a shared Google Document at the same time. There was a moment when "anonymous hedgehog" appeared (see Moment: Anonymous hedgehog below). This new more-than-human entanglement made trouble in our Skype discussion. It took minutes for us to find out that anonymous hedgehog is the name Google Drive chose for one of us. "One of us was identified by Google Drive as anonymous hedgehog!" The burst of laughter and jokes, the joyous moment of collaborative work, the anonymity we often feel in our academic life softening with shared feminist imaginaries. The laugh of Medusa softening the virtual algorithm's automatic technological attribution. This shared fun makes it easier to write-think-talk, to softly segue the "we" again into a different move. Anonymous hedgehog was one of many SF-moments, connecting 
science facts, speculative feminism, speculative fabulation, so far, and science fiction. We wondered if the "hedgehog" was a form of surveillance. We wondered about the misogynistic histories which connect women with animals. We wondered about the racism that connects black people with bestiality. We thought about hedgehogs and extinction. Feeling-with Medusa released these potentials and re-positionings, which connected us across onto-geographies of time and space.

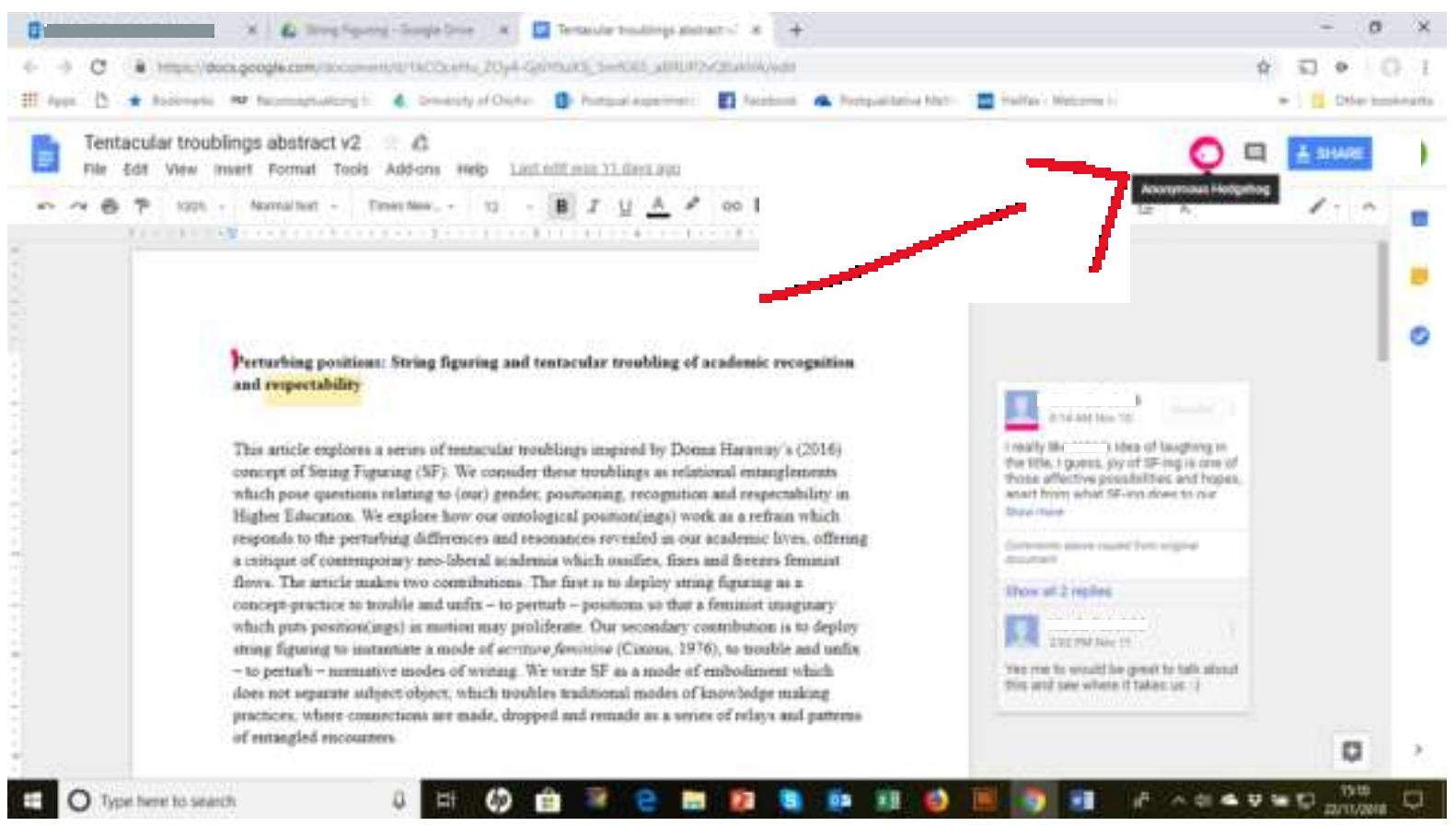

Moment: Anonymous hedgehog

\section{Stringing-With Questions: Perturbing Orientations}

We find ourselves thinking in questions. These include:

"What sort of positioning do we mean?"

"Is this Ahmed's (2010) orientation?"

"Are we saying that ontologically positioning produces capacities for perturbances?"

"Or thinking/wording/feeling with tentacular SF enables this capacity to perturb?"

"What is the relation between tentacular troublings and perturbing positions?"

"Does this relate to our re-ontologising positionality and position?"

"What are these questions of positioning?" 
"How do we include Medusa - or maybe she is already included in the disorder?"

New questions continually emerge as we continue to write-think-talk-laugh. Posing such questions is itself a perturbing practice harnessed to re-configuring new relationalities and capacities in our own position(ing)(s). These position(ing)(s) are in flux and flow in the multiple academia personae we are and are becoming and in our personal lives. Medusaen disorderings encourage us to always start afresh, to keep asking questions. One of us remembers what Heidegger (1962, p. 24) said: "Every inquiry is a seeking. Every seeking gets guided beforehand by what is sought". No, no, no, we say, that's not it. Every inquiry is an opening. Every opening an unforseen cartography of opportunities that take us who knows where. In this, we stand next to Haraway $(2016, p .11)$ who invites us to rearrange "the old things and propos[e] new things, new patterns of feelings and action". Questioning with Medusa makes questions function otherwise, questions become messy, uneasy and tentacular, questions cause trouble. They do not seek answers shaped by the beforehand because they work with these hands here and now in relaying and returning always in new patterns.

SF questions are oriented to how to resist the requirement of the neo-liberal academy that we turn over control of our bodies and minds to its individualising, competitive machine. SF questions displace normative performative visions of rational, "competent" academic, a recognisable "she" who is recognisably "respectable" with fluid and flowing one-two-three-four-more bodies, uncontainable, excessive and joyful. SF questions are Medusaen questions oriented to dis/covering ways of making positionalities-plural possible and means for doing position(alites) differently.

\section{Tentacular Troubling: On the Move with String}

Walking with string. Letting it follow my moves. Hanging down from my hand to the earth, dangling behind me. Walking faster and faster. The string is moving inside my palm. Gliding. Then, suddenly getting stuck. The string twined itself into something. It is no longer I who walk with the string, but the string that prevents me from walking. Stopping. Turning. Releasing the string from the obstacle. Walking slowly. Turning my head to see if the string, my string, is ok. Realising that what I thought was me walking with a string now has turned into the experience of being walked or led by a string. I am following a string - a string is following me - I follow it. The feeling of string in my hand. The feeling of my body attuned to the string; the string attuned to my body.

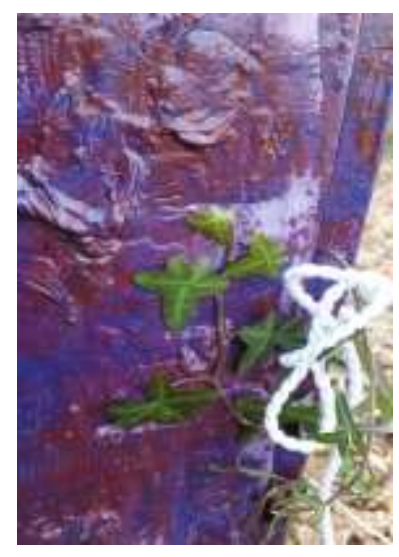


Moment: Ivy and support box

Moment by moment, string and I, particle meeting with particle. Equally. I slowly start tying the string around a box. Admiring the colours. White string, red and purple painted box. Green ivy is growing up and is entwining itself with the purple/red box. The white string breaks with and ties the colours together. The box. The colours. The string. I enjoy the sight of the colours and different materials together. Particle meets particle, but my hand is no longer part of it in the same way as some minutes earlier. Breaking with the string - our time together is over. I untie the string and throw the now greyish, dusty and dirty string in a bin. Brutal. No mercy for my companion in a park in Leuven.

These knotty-perturbances bring other questions to the foreground.

Questions merging throughout the bodily/string-sensing of togetherness.

Questions occurring in a bodily-string overflow.

String composing thoughts in multiplicitous acts.

Questions of becoming a feminist, experiencing being "on the move", thinking on the move. On the move with string provoking SF questions of positionings.

\section{Tentacular Troubling: Pulling Strings}

Did anyone pull any strings for you to be " $(\mathrm{t})$ here"? In your university, as an academic? One of us knows a person whose is $(t)$ here because their father had friends who, when they did not get the required grade, were able to obtain a place for them, a place which positioned them as a student in a desirable university, one well-positioned in the league tables. One of us knows another who followed in their father's footsteps and obtained a position as a Senior Lecturer at his Alma Mater. One of us knows others whose position in life (mother, carer) positioned them outside the walls of academe until they fought hard to get in. One of us knows othered others who have to take the double burden to trouble their non-white/ migrant/mother positionalities, as the pathways to their academic positionalities are bumpier than their white colleagues. Positions as fixings; positions as the ability to fix things; positionalities-plural as the capacity to unfix.

Academic positionality relies on being recognised in/by the university as a respectable body who/which belongs there. This is position as fixed and positionality as sensible, ordered and known. But SF enables positionalities-plural of becoming un/respectable to emerge. SF orients positionality away from education as a "humanising effect" (Snaza, 2015) - in which to be "educated" is to be considered "human"- and towards the potentiality of human-nonhuman positionings. SF puts 
"positionality" in motion so that it might undo those normative and "marked" positions (gendered, race/d, classed, able-bodied).

But, perhaps positionality is already in motion? Perhaps positionality is a proposition, a concept for thinking-in-movement (Manning and Massumi, 2014) which helps activate the potential of the asyet-unknown and as-yet-to-come.

Positionality is an affective and material event. The question of "did anyone pull any strings for you to be ' $(\mathrm{t})$ here?'" and the matter of "when strings are pulled", themselves can position us in particular ways to/think/ feel with these questions. Ahmed's $(2006,2017)$ concept of "orientation" helps us think how to entangle with academic life and extend it to understandings of positional(ities) as relational and affective surfing. One of us is a migrant Asian mother exjournalist who started her PhD research with a thick memories and experiences of the past. She is Medusa, an outsider in the scary unknown. As a PhD candidate/ student the texture of feelings, thinkings and experiences suggest different recognizabilities. During our collaborative string figuring another one of us realizes that being in a position of (PhD) student means you are already in different strings of im/possibilities and knots. You are not in the POSITION of being an academic, you do not have the status of Doctor, you are linearized and positioned in a before-position. You are positioned as prior, in preparation, a novice, a not, a yet-to-become. We need Medusaen positionalities, multiple, moving, extending, making, gazing to trouble this before-position. The knot of race adding to the gendered, mothering/caring/migrant positionalities brings new and different troubles and perturbing transactions. There are pathways to positionalities and to what is and is not within reach, but not everyone has the same directionalities towards what they aim to reach for (Ahmed, 2006). For some it is more difficult to reach towards some positionalities than others. A question: how can you perturb a normative position when you are not in that position yet and are struggling to get to that position?

\section{Tentacular Troubling: Making Feminist Kin}

Making kin with Medusa and Haraway enables us to rethink position(alities) as continual and ongoing feminist work, the work of making kin together as human, non-human, and more-than-human bodies who stay with the trouble in order to "stir up potent response(s)to devastating events, as well as settle troubled waters and rebuild quiet places" (Haraway, 2016, p. 1). Niccolini et al. (2018, p. 331) speak of kinshipping as an "active traffic" of relations, affects and bodies, as a way of shifting "imaginaries [of] recognising subjectivity and difference." SF-ing with Haraway-Medusa is, for us, a mode of kinshipping, a collaborative effort in new ways to do/be academic positionality, recognition and respectability differently.

Medusa, in mainstream cultural imaginaries, is usually described as a formidable threat or a terrible foe. Myths say that just her appearance could turn a man looking at her into stone; others say that it was her gaze that turned the onlooker into stone. Imagining Medusa thus, as masculinist histories have done, surely makes her a disturbance to the idea of rebuilding the quiet places Haraway (2016) 
asks for? No, we don't think so. Medusa can be a productive figuration in the call to rebuild quiet places. Medusa and her Gorgon sisters, Stheno (strength) and Euryale (wide-leaping), lived on an island together beyond the Hesperides, beyond evening, near the end or edge of the world. Together they harboured a hatred of mortal men and their patriarchal laws of the Father. For these reasons, Medusa has long been a figuration for feminist work, a metaphor for feminist power, feminist rage, and feminist agency. Medusa, engirdled with slithering snakes, surrounded by their quivering tongues and gnashing teeth, has (in men's eyes) been someone who needed to be controlled and subdued. In much the same way, the performative and deadening cultures of contemporary higher education seek to control and subdue feminist ideas and women's (and other non-male, nonnormative) bodies, harnessing their work to masculinist neoliberal Euro-American logics. Cixous (1976) tells us that a male perspective of the monstrous Medusa - in producing Medusa as monstrous - was a tool to subjugate women. We look at Medusa. She looks back with encouragement and laughs loudly, urging women to reclaim and regain their embodied feminist identities and rise against patriarchy. We feel Medusa. She is our kin.

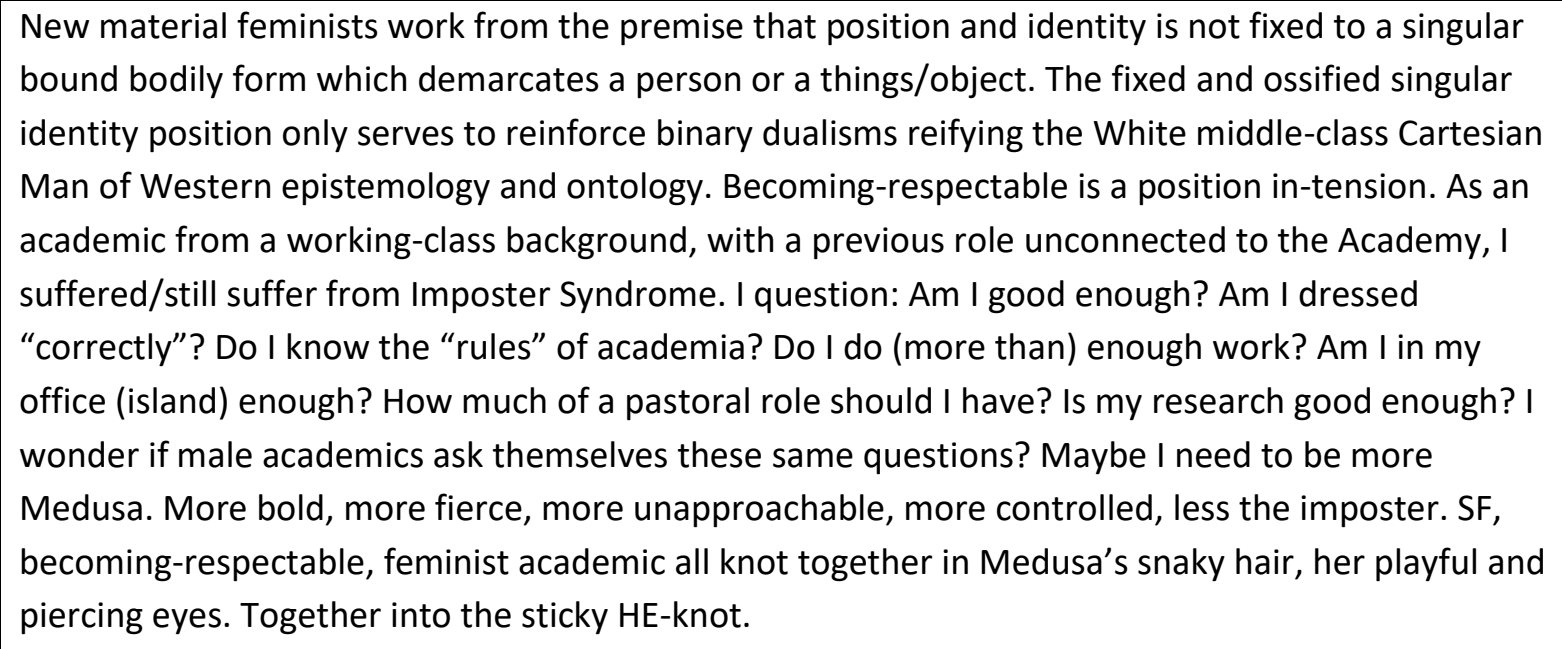

Feeling-Medusa as our kin is an invitation to break the ideas of the perfect dutiful female academic dressed in high-heeled shoes, never wearing a pair of jeans at work, the smiling woman with the tidy hair and ever-ready smile who is often positioned (oh so unconsciously, but how effectively!) as note-maker, minute-taker or coffee-maker, as doer and organiser and carer, for and of the "real" (male) academics. She, this dutiful daughter of the academy, is the woman who strives hard but whose voice goes unheard or is deliberately ignored. She is the woman overlooked for promotion in favour of younger, more streamlined, less messy, less leaky models. She is the one denigrated and ignored in favour of male models who strive, shove, probe and move forward in the relentless march of competitive individualism and virile hegemonic masculinity (Morley, 2016).

Feeling-Medusa refuses feminine respectability in such a toxic culture. Our kinship with Medusa gives us power to question positions and positionalities, including our complicity in positioning others, and 
the extent to which we (however inadvertently, simply for the sake sometimes of getting the job done) produce ourselves in passive positions. Medusa gives us hope - a hope that burns like rage sometimes - to consider what needs to change to take part in creating a better academy, a better world. She is gorgon; she is feminist; she is kin.

\title{
Tentacular Troubling: Making Feminist Fun
}

\begin{abstract}
It matters what matters we use to think other matters with, it matters what stories we tell to tell other stories with; it matters what knots knot knots, what thoughts think thoughts, what descriptions describe descriptions, what ties tie ties. It matters what stories make worlds, what worlds make stories...what Strathern calls "the risk of endless contingency." (Haraway, 2016, p. 12)
\end{abstract}

We had fun at the SF workshop at the PhEmaterialisms conference in Middlesex. The sandwich hoisted on the string. The stringed tampon. The pink string coils on the tree. The string snaking up the street. Is there a feminist theory of fun? Osgood (2019, p. 91) writes of "serious play", and we think-feel that string figuring provides "seriously playful and playful serious foraging method."

At Middlesex, one of us enters in the middle of a white string-figure and a white and red made-rope and starts undoing (un-stringing) an already SF-ed string. This one begins to think how SF might help us to re-tell our stories together in different ways. SF is about touching, sensing and knotting, making stories. It isn't just talking and hearing each other's voices and stories. It is a more-than-voice sensation, a touching-feeling, a storying and memory-ing. One of us considers the trouble with loneliness (being the only one in the workshop undoing and un-stringing the white and red rope), unsure what will come next. The white rope isn't the same anymore, tidy and neat, it becomes longer, messy, and it flows all over the room, on the body, on the floor, becoming unruly rope, it isn't even white anymore but more-than-white, not only one, but many tiny scattered strings which proliferate as more and more string figures emerge.

We laugh, we knot, we tell stories. Medusa's laugh (Cixous, 1967) becomes a powerful act that (re)makes and (re)members our feminist becomings. We (re)member our relational connections with our feminal forebears and our feminist academics here (Middlesex, Leuven, elsewhere) who nourish and mentor us - hearing our unheard songs.

We start walking, outside the room, along the corridors, down the stairs, each part of a collective giant SF, wanting to find a place, a new kin for it. We feel the affective atmosphere of the main hall, we wander around, so many movements, people preparing the place for an event, a round space in the middle with red ropes has made a boundary, one of us steps into the round space, crosses over the red rope to hang our SF in that segregated territorialised space, suddenly a man comes to us and admonishes us, telling us that we cannot enter that space and we cannot hang our SF on the red rope. We wait there a bit longer, we decide to leave our SF there (Moment: re-territorialisation of space with our SF , circled), hanging out with its new kin, the university official thick red rope, our SF 
is hung and hooked there, with all its different knots, colours, shapes, stories, human and more-thanhumans there.

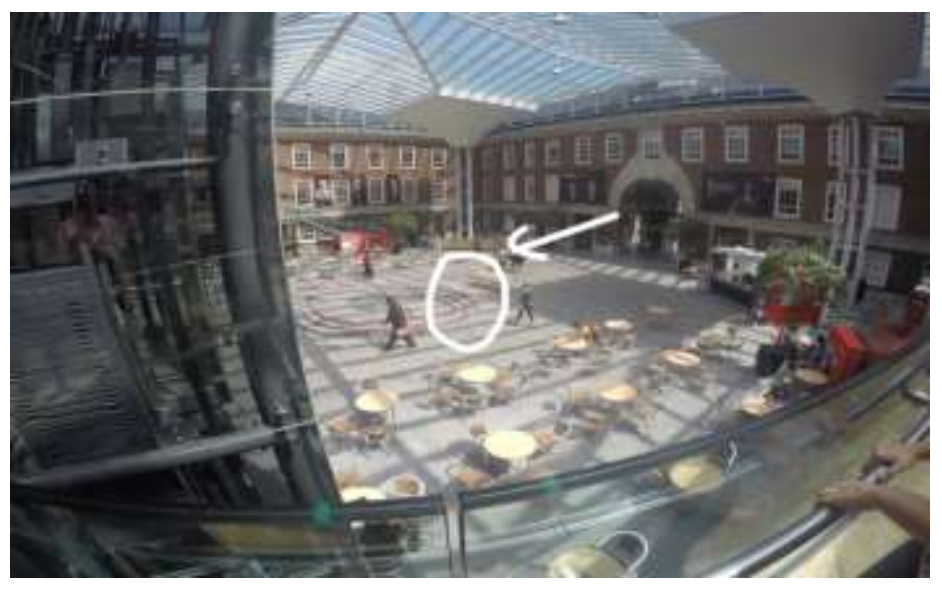

Moment: re-territorialisation of space with our SF

Walking back to the workshop, our hands empty, less heavy, talking about our SF and the man who wanted to stop our kinshipping. We wonder what is going to happen to our SF. We wait at the top of the stairs and watch our SF from a distance (Moment: attached waiting in distance). We feel fondly attached to, entangled with, our SF. We are not looking at it from a detached distance. We keep coming back to check if our SF is still hanging there. It remains there for few hours, a material object positioned, an affective and material presence. SFs are things that stay longer than humans, that decentre the human from the space. SF brings new and different capacities to our political activism, it disrupts, it troubles, it stays, it materialises.

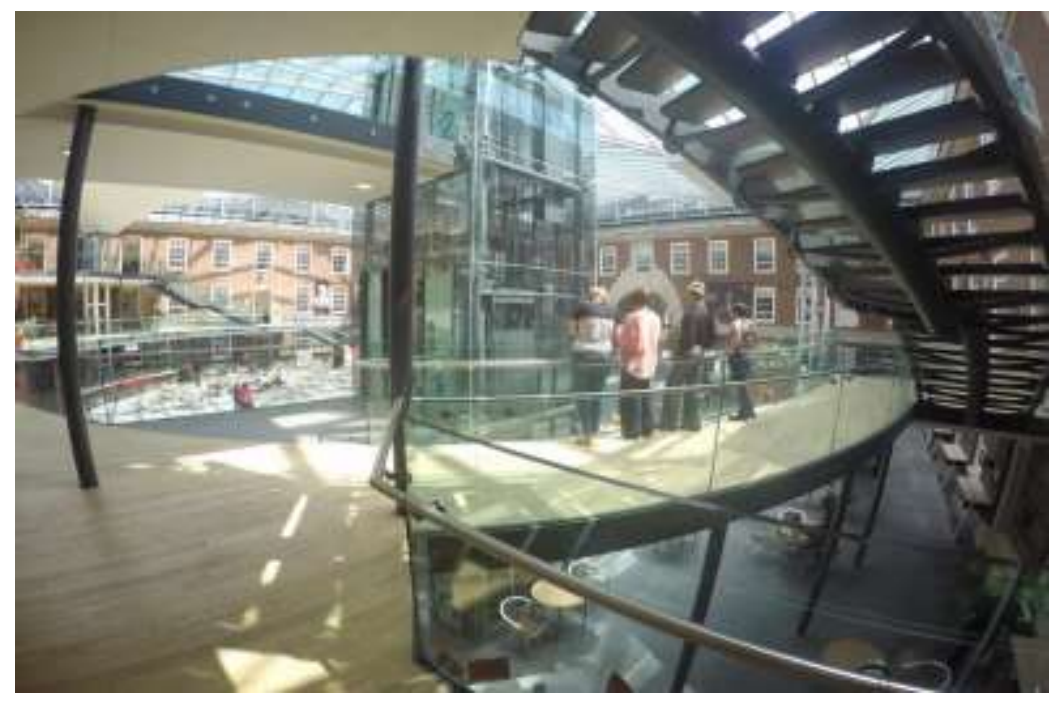

Moment: attached waiting in distance 
How might Medusa respond to making kin in forbidden places? Would she like this instance of feminist fun? Academia has many unwritten rules which only become apparent when transgressed. Our SF engagement is out of place and it knots with our own feelings of sometimes being out of place. We become unrespectable when we take on Medusa's gaze.

Later, when we came out of the workshop, the SF was not there. Perhaps its serious play was too frivolous for the normative, striated academic space in which it was temporarily situated. But no doubt our SF lives on and matters in/through other spaces and times. Here/ there, then/now.

\title{
Tentacular Troubling: Stringing Hope
}

We love the fact that the title 'stringing hope' comes next to this photo-image. Why did we choose this image for stringing hope? Was it accidental? The string in the woman's hand, her wings, the flying horse, and her feet - not touching the ground. The horse and woman already started to jump or fly into something new, pulling new strings. Is this flying happening with pulling of that string? The hope? Why hope? A Medusaen imaginary of our hopeful/hoped for positions to emerge.

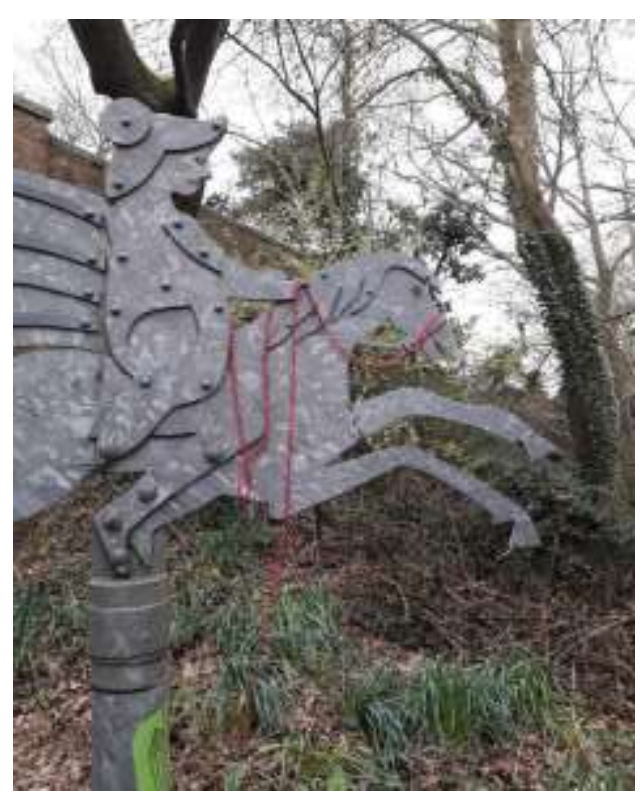

\author{
Air and light \\ Leaf-bright light bright string \\ Curl of string curing a hard surface \\ String and sticky things \\ String and crackle \\ Cackle \\ Knots that knit \\ Sandwich-biscuit-hair-hand \\ The desire of string
}


The stillness to string

Lifelines

A paper plate and pipecleaners

Feet and floor and footwear

Flying fig (don't give a)

Roping red (hold on)

Bloodlines

Absent-presence

Suspended

Here-there-now-gone

A breath

A hint

A twist

A present

A memory tied to a tree

A something braid

A what made

Shimmering string

Hold on and throw up and out and away

Our making-walking-stringing inspires us to think with Haraway who describes hope as a "rapidly mutating virus" (2016, p. 114). The virus of hope? Hope as a virus worth making trouble with? We wonder if Haraway's (2016) ongoing request for staying with the trouble via generative kinshipping, is about hope as a request for (or requirement for) mutating hope by a process of "bringing to crisis" (Spivak, 2002, p.173)? Thinking hope via crisis helps rethink positionalities in HE:

Crisis is an un-anticipatable moment which makes something inherited perhaps jump into something other, and fix onto something that is opposed. For me, crisis is not the leap of 
faith because it brings faith into crisis, but rather is the leap of hope. And that's how I would connect the potential of crisis and hope in resistances of all kinds. (Spivak, 2002, p. 173)

Feeling Medusa and repeating the question, hope for what?, enables those/our Medusaen moments as "leap[s] of hope" (Spivak, 2002, p. 173) which bring a sense of potential to the situation (Massumi, 2002). Crisis-producing hope is a powerful Medusan-Harawayan troubling for generating new positionalities that enable travel outside the tram tracks of expected academic routes and routines. This does not orient hope beyond the present in some form of future feminist utopia, but rather situates us in the here-and-now while lending us the capacity to move beyond the constraints of the given (Colebrook, 2010).

Hope has somehow followed me as a feminist, something that pops up here and there. I wonder whether hope is a kind of 'not worthy' feminist concept, something that turns the focus away from the constant fight feminist perspectives seem to carry. Reading Haraway (2016) awakened my curiosity for something, a thinking/feeling hope that the book somehow pointed towards.

\section{Tentacular Troubling: Making a Feminist Fuss}

As HE academics we are thinking about what Stengers and Despret $(2014$, p. 15) say: 'the party is over' for a certain kind of 'disinterested' pursuit of knowledge in universities. That the party is over for that kind of (middle-aged, male, colonialist, violent) knowledge is, we think, a good thing. And, if it is over, then the time awaits in which we can do some collaborative SF to bring into being/produce a new kind of party to address those who can/are/will be 'taking up the baton.' (Stengers and Despret, 2014, p. 28)

Feminist hope, we think, is about making kin with those who "incite thought" and "resist [by] resuscitating the active memories of" women/ feminists who have previously resisted (Stengers and Despret, 2014, p. 30). Our kinshipping as/with PhEmaterialists move us beyond malestream knowledge practices to new places, just as our string figuring is another form of hope-full staying with the trouble - trouble that makes a fuss, trouble that continues to permeate and proliferate within, trouble that moves with Medusa against/beyond the neoliberal academic machine.

$$
\text { Walking with string. }
$$

Letting it follow the moves - or the moves follow the string

Hanging down from the hand to the earth, dangling

Walking faster and faster

The string is moving inside the palm 
Gliding on the skin

Realising that the string and I are a we; particle in meeting with particle

$$
\text { Then, suddenly - getting stuck }
$$

The string entwined into something, perturbing a different territory?

I am no longer walking with the string - the string prevents me from walking

I have to stop, turning to see what has happened

The string has fastened onto something next to a red and purple painted support-box

A green ivy is growing there - climbing on the colourful box

My white string, the green ivy, the red and purple box

The ivy, string, colours - I cannot help it - my thoughts turn towards hope

Hope is moving

Extending and passing, relay and return, walking and stringing to new moving positionalities-plural. This is our Medusaen feminist hope: to extend, to make kin with humans and more-than-humans, and to stay always in relay and return. To stay with the trouble requires ongoing struggle-ongoing struggle not only with neoliberal higher education but also with our hopes, our dreams and our positions. The support-box and the lively, rough, and tender ivy, the string, colours, fingers - particle meeting particle in a sticky string figure knot. What kind of unexpected collaborations and combinations can come out of this? "We become-with each other or not at all," writes Haraway $(2016$, p. 4). "We have to trust that we can make a difference," writes Stengers (2018, p. 156). Hope entangles in the trust - a hope for changes urged on by the sorts of fuss feminists get to be good at making.

Sometimes the hope is vague and the fuss is small. No matter. How can the sticky knot happening in a small moment in a park far away have an "effect"? Somehow, it can, since it materialises a multispecies response-ability involving a box, ivy, a string and a hand, all of which cross boundaries in making. Somehow, it can, since these small, nearly invisible moves start something. The point is: who or what moves the next string, and what grows from that move, is a praxis by which change can happen, however slowly, in higher education. Unless Medusa shakes her snaky hair and helps speed up the process. 


\section{Tentacular Troubling: SF Writing as Spacetimemattering with New Passing Positions}

We write and PASS, think and PASS, make and PASS, walk and PASS, Skype and PASS. We become nomad, we laugh and become Medusa, we trans/form into technological kin. As SF bodies we gather, conglomerate and proliferate, co-compos(t)ing positionalities-plural in multiple spacetimematterings (Barad, 2007), aware that time and space are "articulated simultaneously in emergent processes of material entanglements and differentiations which challenges tying 'identity' to fixed, particular bodies" (Fairchild and Taylor, 2019, n.p.). The past is never truly and really "past" (as if gone) but reemerges and re-materialises in both present and future (Barad, 2010). Just so our positionalities. Our new positionalities are always moving position/alities, always plural. Passing is our feminist ethicopolitical and onto-epistemological position(s).

As we have already said, this article explores and enacts a mode of SF writing. It grapples with SF writing in the past-present, writing that does not occur in linear time. The flat quiet moment/space in this screenshot (Moment: layering layered) materialises just some of the many layers of our spacetimematterings.

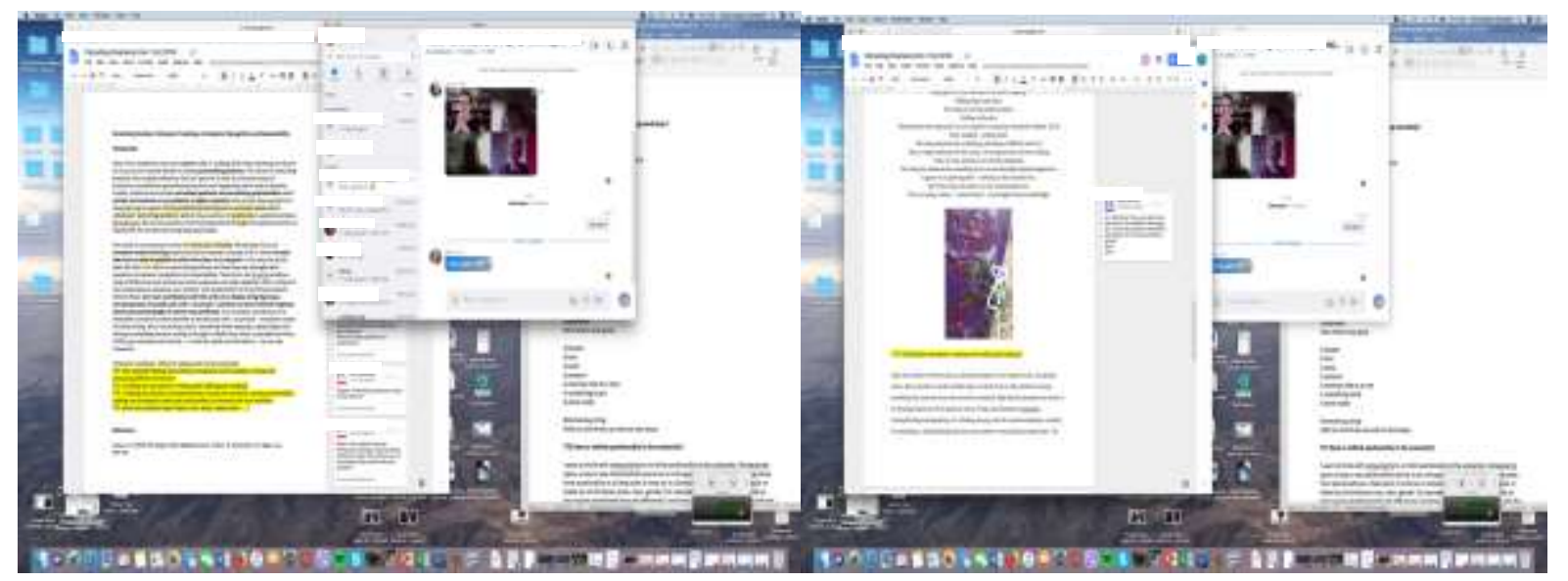

Moment: layering layered

Haraway (2016, p. 112) urges us to consider "what stories we use to tell other stories with". Who/which of us wrote this story? We don't know. We cannot recognise who wrote which part and who added which comment. SF writing pushes beyond the sense of the AcademicWritingMachine where identification of authorship is a requirement in the neoliberal university (Benozzo et al., 2019), where the individual author body is praised for their originality, their contribution, their genius.

Medusa laughs and growls. What tosh, she says. That same old, same old lone hero boring story, she says. That ridiculous masculine fiction again, she says. Our position as authors is as multi-voiced collaborative, an authorly assemblage we have knotted together. A refrain in which the repetitions that emerge are never the same but always different. Which is fine by us. 

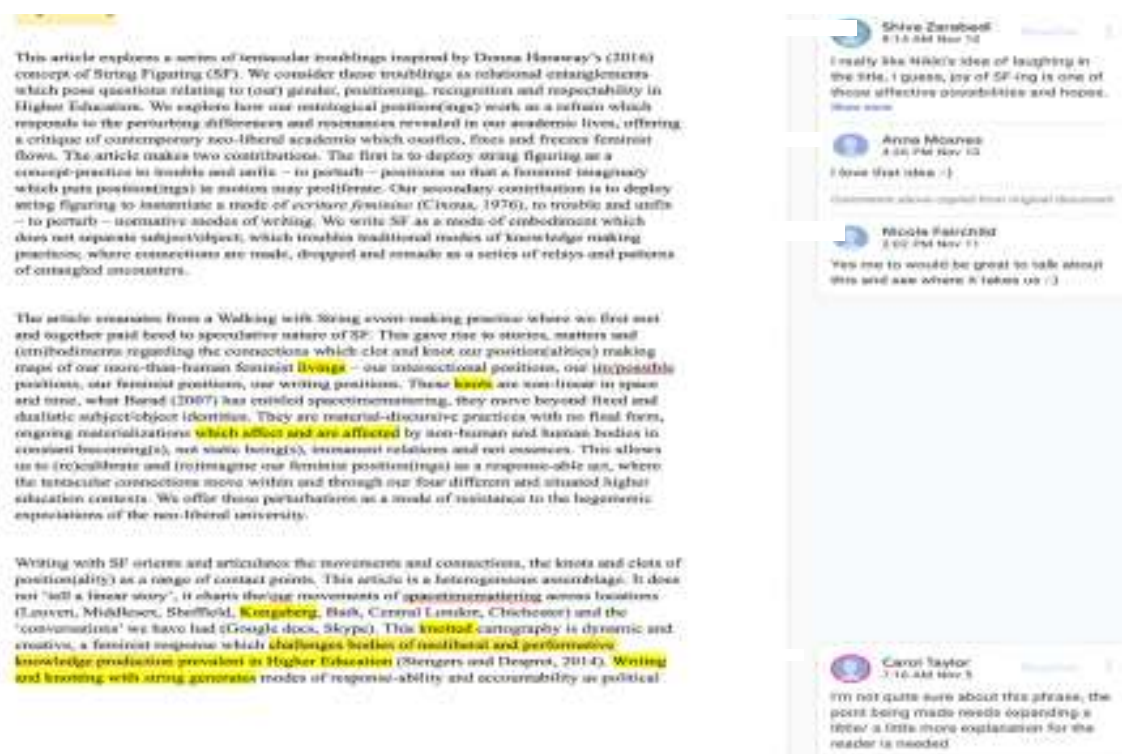

Moment: Multi-voicing

In Skyping and SF-ing, we become more Medusa. We become positionalities-plural when we relay and return with each other's spacetimemattering, when we take/carry/pass with one another's bookshelf, picture frame, curtain, light, bed, colours, door, window, clothes. What sort of agencies are opened up in our spacetimemattering SF-ing? How do we singularly and multiply pass these moving positions? What are we re/positioning when taking pictures from these moving positioning? What does it produce we add our positional view into this SF-ing and positionalities article? We are many in our positions in these particular spacetimemattering frames. We are cat's cradle and cat's cradle is us.

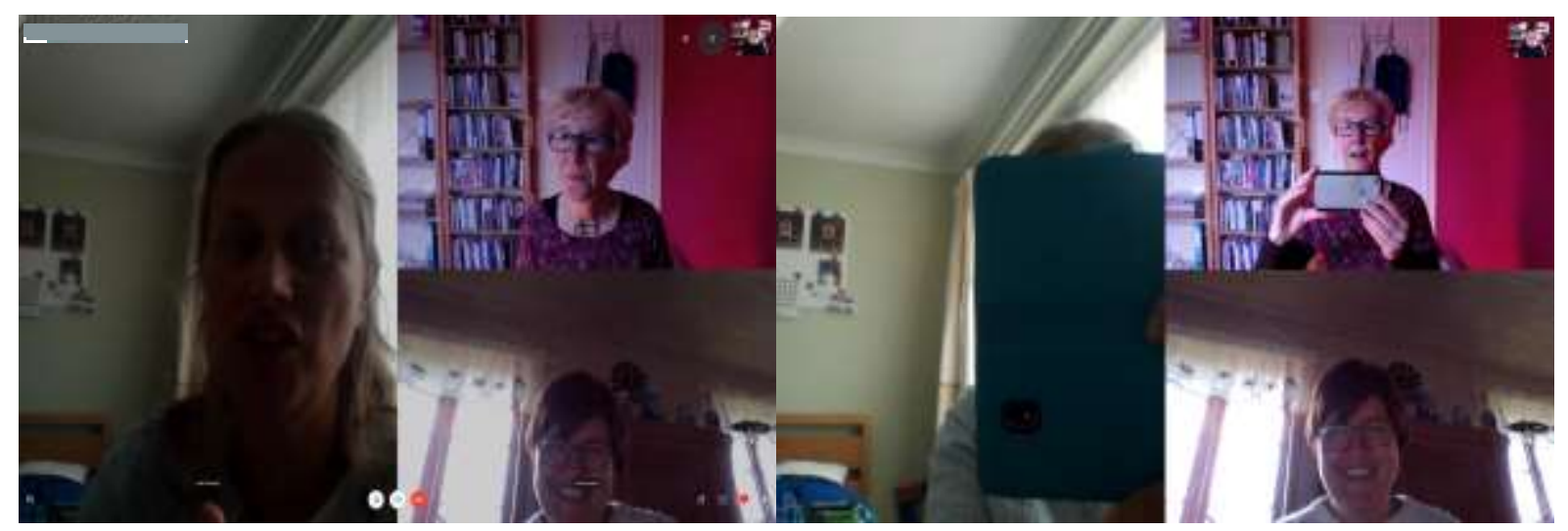

Moment: Cat's cradle "we" 
This is Medusa-fun and Harawayan hope. It is response-ability and accountability to the "we" and the more-than-we that we become and are entangled with. Our passing positionalities-plural are feminist, political and ethical impulses to move beyond dualisms to a more expansive and inclusive field of relations. Our differing/different positionalities are a making of kin which opens to "the patterning of possible worlds" (Haraway, 2016, p. 31).

There are no boundaries between public/private sphere....wife, mother, lecturer...pastoral care in $\mathrm{HE}$...mother(th)ing...gendered positionality...the raft of Medusa...shipwrecked souls waiting for rescue...cannibalism...death...life...success...exhaustion. Medusa's laugh is joyful and affirmative as we flow between these contradictory public/private positions.

\section{Ending (for Now): Knotting, Making Kin and Storying Storied}

The stories we tell in this article work as refrains which enact the flows, differences and repetitions of our positionalities-plural in HE. From the string figuring workshop in Leuven, to the SF knots at PhEmaterialism in Middlesex, to "now", Medusa has been our constant companion, a more-thanhuman provocation, a means to think-with "a host of companions in sympoietic threading, felting, tangling, tracking and sorting" (Haraway, 2016, p. 31). Medusa's snakiness has entangled with our own SF connections, knots, bodyings and experiments to open up feminist possibilities to rethink the fixity of position, to work with tentacular troublings which momentarily bring to the fore our tensions with recognition and respectability in the academy. Medusa has inspired us to imagine new ways of becoming-(un)respectable as a response-able practice, thereby to unfix the recognisable "she" of academia. The nonlinearity of ecriture feminine has generated a collective-collaborative writing which challenges individualised (masculine) modes of authorship: where, we ask, does a body's position stop and another one start? We move beyond humanist notions situated within autoethnography to the relational post-personal bodying which affords us other-than-human SF relationality. Our post-personal collective-collaborative writing instantiates our positions multiple, ever-changing, and immanent as strings are (and continue to be) pulled. Medusa's laugh shakes the walls as our bodily boundaries become blurred. What happens when we/you/l take string for a walk? What play, what joy, what hope in new encounters might ensue? We don't know in advance. What we feel is the power of Medusa as she laughs.

\section{References}

Adams, T. E., Ellis, C. \& Holman Jones, S. (2017) Autoethnography. In J. Matthes, C.S. Davis \& R.F. Potter (Eds.), The international encyclopedia of communication research methods. [online] (accessed 28.10.19).

Adams, T. E. \& Holman Jones, S. (2018) The art of autoethnography. In P. Leavy (Ed.), Handbook of arts-based research (pp 141-164). New York and London: The Guildford Press.

Ahmed, S. (2006). Orientations: Towards a queer phenomenology. GLQ: A Journal of Lesbian and Gay Studies, 12(4), 543-574. https://doi.org/10.1215/10642684-2006-002 
Ahmed, S. (2010). Orientations matter. In D.H. Coole \& S. Frost (Eds.), New materialisms, ontology, agency and politics (pp. 234-257). Durham and London: Duke University Press. https://doi.org/10.1215/9780822392996-011

Ahmed, S. (2017). Living a feminist life. Durham and London: Duke University Press. https://doi.org/10.1215/9780822373377

Barad, K. (2007). Meeting the universe halfway: Quantum physics and the entanglement of matter and meaning. Durham and London: Duke University Press. https://doi.org/10.1215/9780822388128

Barad, K. (2010). Quantum entanglements and hauntological relations of inheritance: Dis/continuities, spacetime enfoldings, and justice-to-come. Derrida Today, 3(2), 240-268. https://doi.org/10.3366/drt.2010.0206

Braidotti, R. (2013). The Posthuman. Cambridge: Polity Press.

Benozzo, A., Koro-Ljungberg, M. \& Adamo, S. (2018) 'Would you prefer not to?' Resetting/resistance across literature, culture, and organizations. Culture and Organization, online. https://doi.org/10.1080/14759551.2018.1532427

Benozzo, A., Carey, N., Cozza, M., Elmenhorst, C., Fairchild, N., Koro-Ljungberg, M., \& Taylor, C. A. (2019). Disturbing the academicconferencemachine: Post-qualitative re-turnings. Gender, Work and Organization, 26(2), 87-106. https://doi.org/10.1111/gwao.12260

Cixous, H. (1976). The laugh of the Medusa (trans. K. Cohen, and P. Cohen). Signs, 1(4), 875-93. https://doi.org/10.1086/493306

Colebrook, C. (2010). Toxic feminism: Hope and hopelessness after feminism. Journal for Cultural Research, 14(4), 323-335. https://doi.org/10.1080/14797581003765291

Deleuze, G. \& Guattari, F (1987) A thousand plateaus: Capitalism and schizophrenia (Trans. B. Massumi). London: Bloomsbury Academic.

Fairchild, N. \& Taylor, C. A. (2019). Karen Barad. In P.A. Atkinson, S. Delamont, A. Cernat, J.W. Sakshaug, \& R.A. Williams (Eds.), SAGE research methods foundations [online]. [Accessed date $-04.10 .19]$.

Gale, K. (2018). Madness as methodology: Bringing concepts to life in contemporary theorising and inquiry. Abingdon: Routledge. https://doi.org/10.4324/9781315159348

Grosz, E. (1994). Volatile bodies: Towards a corporeal feminism. Bloomington and Indianapolis: Indiana University Press.

Haraway, D.J. (1988). Situated knowledges: The science question in feminism and the privilege of partial perspective. Feminist Studies, 14(3), 575-599.

Haraway, D.J. (2016). Staying with the trouble: Making kin in the Chthulucene. Durham and London: Duke University Press. https://doi.org/10.1215/9780822373780

Heidegger, M. (1962). Being and time. New York: Harper and Row.

Hemmings, C. (2012). Affective solidarity: Feminist reflexivity and political transformation. Feminist Theory, 13(2), 147-161. https://doi.org/10.1177/1464700112442643

Hughes, H. E., Bridges-Rhoads, S. \& Van Cleave, J. (2018). Work/think/play in qualitative and post qualitative inquiry. Qualitative Inquiry, 24(9), 599-602. https://doi.org/10.1177/1077800417733499 
Manning, E. \& Massumi, B. (2014). Thought in the act: Passages in the ecology of experience. Minneapolis, MN: University of Minnesota Press. https://doi.org/10.5749/minnesota/9780816679669.001.0001

Massumi, B. (2002). Navigating movements. In M. Zournazi (Ed.), Hope: New philosophies for change (pp. 210-242). Pluto Press, Sydney.

Massumi, B. (2014). What animals teach us about politics. Durham: Duke University Press. https://doi.org/10.1215/9780822376057

Morley, L. (2016). Troubling intra-actions: Gender, neo-liberalism and research in the global academy. Journal of Education Policy, 31(1), 28-45. https://doi.org/10.1080/02680939.2015.1062919

Moxnes, A. R. (2019). Sensing, thinking and doing reflection in early childhood teacher education (Doctoral dissertation). University of South-Eastern Norway, Drammen.

Muhr, S. L. \& Rehn, A. (2015). On gendered technologies and cyborg writing. Gender, Work and Organization, 22(2), 129 - 138. https://doi.org/10.1111/gwao.12057

Niccolini, A.D., Zarabadi, S. \& Ringrose, J. (2018). Spinning Yarns: Affective Kinshipping as Posthuman Pedagogy. Parallax, 24(3), 324-343. https://doi.org/10.1080/13534645.2018.1496582

Osgood, J. (2019). Materialised reconfigurations of gender in early childhood: Playing Seriously with Lego. In J. Osgood \& K.H. Robinson (Eds.), Feminists researching gendered childhoods: Generative entanglements (pp. 85-108). London Bloomsbury. https://doi.org/10.5040/9781474285810.ch-005

Otterstad, A. M. \& Waterhouse, A-H.L. (2016). Beyond regimes of signs: Making art/istic portrayals of haptic moments/movements with child/ren/hood. Discourse: Studies in the Cultural Politics of Education, 37(5), 739-753. https://doi.org/10.1080/01596306.2015.1075727

Pedwell, C. \& Whitehead, A. (2012). Affecting feminism: Questions of feeling in feminist theory. Feminist Theory, 13, 115. https://doi.org/10.1177/1464700112442635

Prasad, A. (2016). Cyborg writing as a political act: Reading Donna Haraway in organization studies. Gender, Work and Organization, 23(4), 431-446. https://doi.org/10.1111/gwao.12128

Skeggs, B. (1997). Formations of class and gender: Becoming respectable. London: Sage.

Snaza, N. (2015). Towards a genealogy of educational humanism. In N. Snaza \& J. A. Weaver (Eds), Posthumanism and educational research (pp. 17-29). Abingdon: Routledge. https://doi.org/10.4324/9781315769165

Spivak, G. (2002). The rest of the world. In M. Zournazi (Ed.), Hope: New philosophies for change (pp. 172-191). Pluto Press, Sydney.

Stengers, I. (2018). Another science is possible: A manifesto for slow science. Cambridge: Polity Press. Stengers, I. and Despret, V. (2014). Women who make a fuss: The unfaithful daughters of Virginia Woolf. Minneapolis, MN. University of Minnesota Press.

Taylor, C. A. (2017) For Hermann: How do I love thee? Let me count the ways. Or, what my dog has taught me about a post-personal academic life. In S. Riddle, M.K. Harmes \& P.A. Danaher (Eds.), Producing Pleasure in the contemporary university: Bold visions in educational research (pp. 107-119). Sense Publishers, Rotterdam. https://doi.org/10.1007/978-94-6351179-7_9 
Taylor, C. A., Fairchild, N., Koro-Ljungberg, M., Benozzo, A., Carey, N., \& Elmenhorst, C. (2019). Improvising bag choreographies: Disturbing normative ways of doing research. Qualitative Inquiry, 25(1), 17-25.

Van der Tuin, I. (2015). Generational feminism: New materialist introduction to a generative approach. Lanham, Maryland: Lexington Books.

Waterhouse, A-H. L., Otterstad, A. M. \& Jensen, M. (2016). ...anything but synchronized swimming/methodologies... artistic movements in/with unknown inventions. Qualitative Inquiry, 22(3), 201-209. https://doi.org/10.1177/1077800415605063

Wolgemuth, J., Rautio, P., Koro-Ljungberg, M., Marn, T., Nordstrom, S. \& Clark, A. (2018). Work/think/play/birth/death/terror/qualitative/research. Qualitative Inquiry, 24(9), 712-719. https://doi.org/10.1177/1077800417735860 